\title{
Perempuan dan Politik Lokal (Studi Kasus Pemilihan Kepala Daerah di Sulawesi Tenggara)
}

\author{
Hadi Machmud \\ Fakultas Tarbiyah dan Ilmu Keguruan Institut Agama Islam Negeri Kendari, Indonesia \\ machmud657@gmail.com
}

\begin{abstract}
This qualitative study aimed to investigate the existence of women's contestation in the local election in South East Sulawesi and to identify the female candidates' effort to win the electoral competition. Data gathered from interview, observation, and documents were analyzed based on the analytical framework used. Findings of the study reveal that the contestation of female regency or major candidates has been of great consideration due to their previous strategic ruling position in the government, such as vice of major, head of the local house of representative, member of the house of regional representative, and local government secretary. Furthermore, the female candidates have a big chance to succeed in the election regarding that they have big force, and their offered programs are beneficial for women and marginal communities. These female candidates also involve more female volunteers' force who is competent and potential in running activities along with women organization and aiming at empowering women communities.
\end{abstract}

Keywords: regional election; woman; dynasty; patriarchy

\begin{abstract}
Abstrak
Penelitian ini difokuskan pada perempuan calon peserta Pilkada, berjumlah 4 orang, yakni; 1 orang Kabupaten Konawe dan Kolaka, 2 orang Kota Bau-Bau.Data diperoleh melalui wawancara, catatan lapangan, pengamatan langsung, dan dokumentasi. Hasil penelitian: Perempuan kontestan Pilkada Sulawesi Tenggara adalah tokoh publik/pejabat, anggota parlemen; calon Walikota Bau-Bau ketua DPRD dan Wakil Walikota, Konawe anggota DPD RI, Kolaka Sekda Kolaka. Peluang menjadi Bupati dan Walikota sesungguhnya cukup besar mengingat mereka memiliki basis massa jelas, visi, misi dan program kerja yang berpihak pada perempuan, rakyat kelas bawah, telah melakukan berbagai upaya memenangkan kompetisi; sosialiasi, kampanye, blusukan ke daearah, ketempat yang mayoritas penduduk dan DPT yang besar, bekerjasama dengan organisasi/kelompok dan LSM perempuan, memaksimalkan tim sukses dan relawan, namun hasil Pilkada tidak ada calon perempuan yang berhasil lolos.
\end{abstract}

\section{Kata Kunci: perempuan; politik lokal, dinasti; patriarki}

\section{A. Pendahuluan}

Indonesia adalah negara yang menjunjung tinggi nilai-nilai demokrasi, Negara memberikan hak dan kedaulatan yang sama kepada semua warga negara sebagai bentuk kedaulatan. Dalam sistem demokrasi, rakyat memiliki peran yang sangat urgen dalam menentukan arah dan kebijakan negara. Posisi rakyat menjadi penting dalam sistem demokrasi terutama dalam menentukan suatu tatanan bentuk pemerintahan. Pemerintahan di legitimasi melalui proses pemilihan, yang dikenal dengan pemilihan kepala daerah atau pilkada. Pemilihan kepala daerah dilaksanakan untuk memilih pemerintah yang memimpin suatu daerah dalam jangka waktu tertentu apakah itu tingkat Provinsi atau Kabupaten/Kota. 
Undang-undang no 10 tahun 2016 tentang perubahan kedua atas undang-undang nomor 1 tahun 2015 tentang penetapan peraturan pemerintah pengganti undang-undang nomor 1 tahun 2014 tentang pemilihan Gubernur, Bupati, dan Walikota menjadi undang-undang, telah mengatur semua proses pelaksanakan Pilkada. Ada banyak pasala yang mengatur tentang proses pelaksanaan pilkada, terutama pensyaratan menjadi calon peserta pemilihan kepala daerah (Pilkada), seperti pasal 7 ayat 1 dan 2, yakni tentang hak setiap warga negara untuk mencalonkan diri dan persyaratan menjadi calon Gubernu dan Wakil Gubernu, Bupati dan Wakil Bupati, Walikota dan Wakil Walikota ${ }^{1}$.

Keterwakilan perempuan dalam Pilkada tahun 2018 di Sulawesi Tenggara menunjukkan atmosfir demokrasi yang ramah tidak biasa gender sekaligus menjadi fenomena kebangkitan perempuan yang ingin disejajarkan dengan kaum laki-laki dipentas politik. Betapa tidak pesta demokrasi yang digelar dari tahun ke tahun di daerah ini baru pelaksanaan Pilkada tahun inilah ada kontestan perempuan, dimana bila kita menengok kebelakang pada pelaksanaan pilkada sebelumnya perempuan hanya sebagai/menjadi wakil Bupati. Gairah politik perempuan yang menunjukkan semangat kompetitor turut mewarnai semaraknya pentas panggung demokrasi, diharapkan berbanding lurus dengan hasil maksimal dengan potensi yang dimilki, bukan hanya sebatas pelengkap pemenuhan pensyaratan bagi partai sebagai peserta pemilu dan bukan pula pelestarian dinasti politik yang nampaknya turut mewarnai pesta demokrasi yang digelar diseluruh nusantara.

Menjadi wacana umum bahwa tahun ini sering disebut sebagai tahun politik, dimana tahun ini dilaksanakan pemilihan kepala daerah secara serentak pada 171 daerah dan 17 di tingkat provinsi dan 39 kota serta 115 Kabupaten pada tanggal 27 Juni 2018². Salah satu daerah yang melaksanakan pemilihan kepala daerah adalah Sulawesi Tenggara, yang akan melaksanakan pemilihan Gubernur dan Bupati serta Walikota, yaitu Kabupaten Konawe dan Kabupaten Kolaka danKota Bau-Bau. Dari 3 daerah yang melaksanakan pemilihan kepala daerah, semunya memiliki calon Bupati dan Walikota perempuan berjumlah 4 orang dengan rincian adalah yang berasal dari unsur perseorangan 1 orang calon, dan usungan dari gabungan partai 3 orang calon yaikni; Kabupaten Kolaka 1 orang calon, Kabupaten Konawe 1 orang calon, dan Kota Bau-Bau 2 orang calon.

Partisipasi perempuan dalam pilkada tahun 2018 meningkat 8,85\%(101 perempuan dari 1.140 calon yang berkompetisi) bila dibandingkan dengan pilkada tahun 2015 dan 2017. Hal ini berdasarkan Peneliti dari Perludem (Perkumpulan untuk Pemilu dan Demokrasi) Mahardika yang menjelaskan bahwa ada 49 perempuan yang mendaftar menjadi calon kepala daerah, 2 orang calon Gubernur, 31 orang calon Bupati dan 16 orang calon walikota. Selain itu ada 52 perempuan yang menjadi calon wakil kepala daerah, 5 orang calon wakil Gubernur, 28 orang calon wakil Bupati dan 18 orang calon wakil Walikota ${ }^{3}$. Direktur Eksekutif Perludem Titi Anggraini mengatakan perempuan dan pemilu menjadi suatu keniscayaan yang tidak dapat dipisahkan satu dengan lainnya ${ }^{4}$. Selanjutnya dikatatakan bahwa melalui pemilu perempuan dapat mengisi kursi-kursi pimpinan pemerintah daerah dalam rangka menghasilkan kebijakan yang responsif gender.

Performance pemilihan kepala daerah yang digelar secara serentak di seluruh Nusantara nampaknya belum sepenuhnya memberikan akses maksimal bagi partisipasi politik

${ }^{1}$ Undang-Undang Nomor 10 Tahun 2016 Perubahan Kedua Undang-Undang Nomor 1 Tahun 2015 Tentang Penerapan Peraturan Pemerintah Pengganti Undang-Undang Nomor 1 Tahun 2014 Tentang Pemilihan Gubernur, Bupati Dan Walikota.

${ }^{2}$ KPU dan Bawaslu Sulawesi Tenggara 2017

${ }^{3}$ Prasetyo Teguh,. Pemilu Bermartabat (Reorientasi Pemikiran Baru Tentang Demokrasi, (Jakarta: Raja Grafindo Persada, 2017)

${ }^{4}$ Kementerian Pemberdayaan Perempuan dan Anak. https:kemenpppa.go.id 
perempuan dan belum utuh memberikan kesempatan terpenuhinya affirmative action, padahal sesungguhnya inilah kesempatan baik bagi perempuan untuk dapat menghubungkan perempuan dengan negara. Mencermati dinamika politik perempuan pada pilkada dan keterwakilan perempuan pada pilkada 20018 yang mengalami grafik peningkatan signifikan dibandingkan tahun sebelumnya memberikan harapan positif bagi perempuan untuk dapat memperoleh suara terbanyak dan mampu menggeser posisi kontestan laki-laki.

Eksistensi perempuan dalam kompetisi perhelatan pemilihan pemimpin daerah Kabupaten/Kota di Sulawesi Tenggara sangat diperhitungkan, mengingat kompetensi perempuan selama ini disemua ranah menempati posisi strategis, sehingga menjadi pertimbangan dan perhatian tersendiri bagi partai untuk pengusung perempuan menjadi calon. Kondisi ini menepis stigma bahwa perempuan hanyalah sebagai pelengkap, pendulang suara dan mobilisasi suara untuk memenangkan calon dari kaum elit laki-laki. Kehadiran kontestan perempuan dalam kancah politik Pilkada memberikan keseimbangan dan kesetaraan politik yang mengasumsikan setiap orang seharusnya menghitung satu dan tidak satupun boleh melebihi yang lain ${ }^{5}$ Lebih jauh dijelaskan bahwa Pilkada diharapkan menjadi satu mekanisme politik yang merepresentasikan kemampuan perempuan dalam jabatan politik ditingkat lokal, hal ini dikarenakan kaum perempuan memliki populasi yang hampir berimbang dengan laki-laki.

Keterwakilan perempuan dalam kancah politik baik mereka sebagi anggota parlemen, yakni anggota DPD, DPR RI, DPRD Provinsi dan Kabupaten Kota nampaknya masih sebatas pemenuhan kuota $30 \%$ yang dipersyaratkan, namun kontribusi dan kerja nyata yang ditelorkan untuk kesejahtraan masyarakat khusunya bagi kaum perempuan belum bisa dirasakan, mereka masih begelut dengan masalah dan hal-hal teknis pada tufoksi di komisi/bidang masing-masing. Demikian pula dengan perempuan yang menjadi birokrat, program yang turut ditelorkan seharusnya berafiliasi dan bersentuhan langsung dengan kaum perempuan. Dengan demikian sejatinya mereka sudah mempunyai modal untuk melakukan kompetesi di pemilihan kepala daerah.

Para pakar pemerhati politik perempuan telah melakukan kajian dan riset peran perempuan baik pada ranah domestik maupun ranah publik, namun yang paling banyak menjadi sorotan adalah keterwakilan perempuan di ranah publik/politik, yang terkhusus adalah keterpenuhan affirmation action keterwakilan perempuan. Bagi partai yang menjadi peserta pemilu yang tidak memiliki pengurus atau anggota perempuan yang dapat diusung menjdi calon pada pilkada di daerah-daerah berusaha dan berlomba untuk menemukan perempuan yang dinggapa memiliki kompetensi, kulaitas dan kapasitas yang dapat diusung untuk menjadi calon dalam pelaksanaan pilkada. Seringkali partai politik kerepotan mendapatkan perempuan yang idel, hal ini terjadi dikarenakan partai politik krisis kader sebagi tokoh perempuan yang kharismatik yang dapat diterima di semua kalangan.

Kehadiran perempuan dalam kancah pertarungan Pilkada Kabupaten Kota di Sulawesi Tenggara sebagai kandidat calon kepala daerah di tiga kabupaten/Kota yaitu: Dr. Hj. Asmani Arief untuk Kabupaten Kolaka, Muliati Saiman S.Si untuk Kabupetn Konawe, serta Hj. Roslina Rahim dan Hj. Wa Ode Maasa Manarfah untuk Kota Bau-Bau menjadi barometer kompetisi kontestasi di daerah ini. Sejak ditetapkan oleh Komisi Pemilihan Umum (KPU) Provinsi Sulawesi Tenggara dan telah melalui semua tahapan perifikasi yang dipersyaratkan oleh KPU maka para kandidat sudah mulai melakukan sosialisasi dan kompetisi Memasuki tahapan kampanye, para kandidat memperguankan semua strategi, momen, waktu, dan

5 Suswantoro Gunawan, Mengawal Penegak Demokrasi di Balik Tata Kelola Bawaslu \& DKPP, (Jakarta: Erlangga, 2016). 
tempat yang tidak melanggar regulasi untuk melakukan sosialisasi dan kampanye serta menawarkan vis, misi, dan program untuk menarik dan mempengaruhi para pemilih..

Perjuangan perempuan colon peserta Pilkada di Sulawesi Tenggara tahun ini untuk berlaga di pilkada serentak memang tidaklah mudah mengingat kompetitornya mereka adalah laki-laki yang sudah mempunyai kompensi, pengalaman, nama yang mumpuni, dukungan dari basis yang jelas, serta dukungan dari partai, keluarga dan bahkan adalah petahana,hal ini menjadi modal yang sangat berharga bagi setiap kontestan. Ikhtiar besar harus dilakukan semua kandidat mengingat semua kontestan baik perempuan maupun laki-laki adalah pelaku politik publik yang sudah punya pengalaman baik menjadi legislatif ditingkat daerah dan nasional maupun sebagai kepala Daerah Bupati dan Walikota incumben, dan juga dari birokrat.

Para kandidat calon Bupati dan Walikota dari kalangan perempuan yang akan bertarung di Pilkada sesungguhnya tidaklah mudah memperoleh tiket untuk maju menjadi calon. Mereka harus berjuang ditingkat partai poltik untuk memperoleh dukungan, mengingat ada orang lain yang juga mempunyai hajat yang sama. Ripal mereka dalam memperoleh tiket dari partai tidak hanya datang dari anggota partai tetapi juga dari yang bukan anggota atau pengurus partai. Banyak pertimbangan yang dilakukan partai peserta pemilu untuk memilih dan penetapkan setiap calon yang akan diusung dalam pilkada di masing-masing Kabupaten Kota. Berdasarkan fenomena dan data awal yang diperoleh, maka penulis ingin mengetahui lebih jauh bagaimana sesungguhnya eksistensi perempuan di Sulawesi Tenggara mengambil peran dalam Pemilihan Kepala Daerah untuk menjadi orang nomor satu menduduki takhta pemimpin di masing-masing daerah. Seberapa besar peluang mereka memenangkan kompetisi yang dihelat secara serentak di seluruh nusantara, dimana dari 3 daerah Kabupaten Kota di Sulawesi Tenggara yang melaksanakan Pilkada semua menempatkan perempuan sebagai calon perempuan.

Riset yang difokuskan pada kiprah perempuan dalam dunia politik khususnya keterlibatanya dalam politik lokal di beberapa wilayah Indonesia telah banyak dilakukan, diantaranya dilakukan oleh Marwah dalam pemilihan bupati serentak di Jawa Tengah Tahun $2015^{6}$. Penelitian ini menemukan bahwa representasi perempuan yang terpilih menjadi bupati yaitu 3 orang dan wakil bupati 6 orang. Meskipun demikian, keberhasilan perempuan sebagai bupati di Kabupaten Grobogan, Kendal dan Klaten, setidaknya dapat menjadi cermin kemampuan perempuan dalam menduduki jabatan publik. Penelitian Wahid dalam Pemilukada DKI Jakarta tahun 2012 menmukan bahwa kekuasaan perempuan dalam politik di provinsi DKI Jakarta masih sangat minimum dibanding dengan kaum laki-laki yang selama ini mendominasi politik, bahkan perempuan belum pernah ada yang mencalonkan diri dan dicalonkan oleh partai politik sebagai kandidat Gubernur dan Cawagub ${ }^{7}$. Penelitian tentang keterwakilan perempuan di Sulawesi Tenggara telah dilakukan oleh Zainal ${ }^{8}$ yang menemukan bahwa dari delapan orang legislator perempuan, 6 orang atau $75 \%$ lahir dari rahim kekuasaan.

\footnotetext{
${ }^{6}$ Sofa Marwah, "Representasi Perempuan Dalam Pemilihan Bupati Dan Wakil Bupati Serentak Di Jawa Tengah Tahun 2015”, JURNAL POLITIK, VOL.1, NO. 2, (Februari 2016): 264-281.

${ }^{7}$ Umaimah Wahid, "Perempuan Dan Kekuasaan Politik Dalam Pemilukada Dki Jakarta Tahun 2012", Jurnal Komunikasi Malaysian Journal of Communication Jilid 29(1) 2013: 73-97

${ }^{8}$ Asliah Zainal, "Politik Berjenis Kelamin Laki-laki (Keterwakilan Perempuan Di DPRD Provinsi Sulawesi Tenggara Pada Pemilu 2014)", Jurnal Al Izzah Vol. $10 \quad$ No. 1 2015, http://ejournal.iainkendari.ac.id/index.php/al-izzah/article/view/325. http://dx.doi.org/10.31332/ai.v10i1.325
} 
Keterlibatan ataupun kemenangan perempuan dalam pertarungan politik ternyata tak bisa dipungkiri melibatkan kekuasaan laki-laki, baik sebagai suami, bapak, anak, dan seterusnya. Penelitian Maula di Jombang yang memenangkan $\mathrm{Hj}$ Munjidah Wahab yang merupakan putri seorang ulama besar di Jombang. Keterpilihan Hj. Munjidah sebagai bupati ini bagaimanapun telah merubah paradigma berfikir kaum laki-laki yang bias gender untuk memberikan ruang kepada perempuan dalam dunia politik, sekaligus juga memberikan energi positif didalam relasi politik antara laki-laki dan perempuan. Penelitian Lotulung \& Mulyana di Sulawesi Utara dan menemukan bahwa nama keluarga yang melekat pada nama belakang perempuan sebagai salah satu ciri budaya patriarkhi, baik yang berasal dari nama ayah maupun suami yang popular secara politik, menjadi modal tersendiri guna memperlancar perempuan masuk dunia politik.

Modal sosial, ekonomi, kultural, dan politik perlu dimiliki perempuan dalam memenangkan kontestasi politik. Jika tidak, maka kehadiranya tidak akan banyak bermakna bagi masyarakat. Sebagaimana penelitian yang dilakukan Iskandar tentang terpilihnya Wali Nagari Batu Basa Kecamatan Pariangan Kabupaten Tanah Datar Tahun 20099. Penelitian ini menemukan bahwa elektabilitas Bariana bukan saja karena pengalaman lama sebagai PNS, tetapi juga hidup dengan modal kepercayaan masyarakat yang ternyata tidak lagi mempersoalkan jenis kelamin. Kenyataan itu, dalam batas tertentu memperlihatkan masyarakat Batu Basa cenderung rasional dalam menjatuhkan pilihannya, meskipun masih dalam level kecil pada Wali Nagari.

Penelitian ini akan memperkaya penelitian-penelitian yang sudah dilakukan sebelumnya pada lokus politik local di salah satu kabupaten di Sulawesi Tenggara. Bagaimanapun, penelitian ini berbeda dengan penelitian-penelitian sebelumnya, dimana perempuan-perempuan yang maju dalam politik di ajang Pilkada di Sulawesi Tenggara adalah perempuan yang berasal dari tokoh publik/pejabat dan juga petahana sebagai anggota legislative. Dengan demikian, perempuan-perempuan tersebut memiliki modal social, ekonomi, dan modal politik yang cukup kuat. Namun demikian, modal sosial, ekonomi, dan politik tersebut tidak menjadi tiket yang meloloskan jalan mereka menjadi penguasa di tiga wilayah Sulawesi Tenggara, yaitu di Kabupaten Konawe, Kabupaten Kolaka, dan Kota BauBau.

Penelitian ini adalah penelitian kualitatif, yang memfokuskan pada permasalahan "perempuan yang menjadi calon kontestan dalam pelaksanaan pemilihan kepala daerah di Kabupaten Kolaka, Konawe dan Kota Bau-Bau. Pengumpulan data menggunakan teknik observasi, dan wawancara mendalam serta dokumentasi. Analisis data dilakukan melalui proses penyeleksian data, selanjutnya dilakukan klasifikasi, penyimpulan serta uji ulang. Data yang terkumpul disaring dan diklasifikasi dalam berbagai kategori, kemudian dihubungkan antara satu dan yang lainnya. Tujuannya adalah untuk memperkokoh dan memperluas bukti yang akan dijadikan dasar bagi pengambilan kesimpulan. Pengujian dilakukan terhadap interpretasi data sebelumnya di dalam uraian logis atau kausal untuk memperoleh bukti penguat kesimpulan dari berbagai sumber. Selanjutnya data dicek keabsahannya dengan triangulasi yakni triangulasi teori, teknik, waktu dan teman sejawat.

\section{B. Perempuan Peserta Pilkada}

Penyelenggaraan Pemilihan Kepala Daerah (Pilkada) dilaksanakan seiring dengan perkembangan dinamika politik yang terus digulirkan sejak reformasi. Ruang politik yang

${ }^{9}$ Israr Iskandar, "Wali Nagari Perempuan Di Era Reformasi: Studi Kasus Terpilihnya Wali Nagari Batu Basa Kecamatan Pariangan Kabupaten Tanah Datar Tahun 2009”, Aspirasi Vol. 2 No. 1, (Juni 2011 ): $97-$ 110 
selalu menjadi diskusi adalah refresentasi keikutsertaan perempuan dalam kompetisi Pilkada. Undang-undang nomor 10 tahun 2016 perubahan kedua undang-undang nomor 1 tahun 2015 tentang penerapan peraturan pemerintah pengganti undang-undang nomor 1 tahun 2014 tentang pemilihan Gubernur, Bupati dan Walikota, telah mengatur eksistensi perempuan dalam bursa pemilihan kepala daearah. Hal ini jelas dinyatakan dalam pasal 7 ayat 1 bahwa "setiap warga negara berhak memperoleh kesempatan yang sama untuk mencalonkan diri dan dicalonkan sebagai calon Gubernur dan wakil Gubernur, Calon Bupati dan Calon wakil Bupati, serta Calon Walikota dan Calon Wakilkota”. Dalam peraturan Komisi Pemilihan Umum nomor 1-5 tentang pemilihan serentak dijelaskan tentang bagaimana pemilihan kepala daerah dilaksanakan secara serentak di seluruh Indonesia, demikian pula dengan peraturan Badan Pengawas Pemilihan Umum telah dibuat untuk mengatur pelaksanaan pengawasan Pilkada serentak.

Pemberlakuan Undang-Undang Pilkada nomor 10 tahun 2016 yang responsif gender senafas dengan prespektif liberal klasik yang menyatakan tidak perlu ada pembedaan antara laki-laki dan perempuan, harus ada kesempatan dan kesetaraan untuk berkompetitip. Dahlerup ${ }^{10}$ menyatakan bahwa kesetaraan dalam prespektif kesempatan antara laki-laki dan perempuan adalah kesempatan yang "setara" atau kesetaraan yang kompetitip, merupakan kebijakan untuk menghilangkan penghalang formal dengan memberikan hak pada perempuan. Prespektif ini percaya bahwa wilayah politik adalah wilayah yang bebas bagi semua orang baik laki-laki maupun perempuan untuk dapat bersaing/berkompetisi memperebutkan posisi dan jabatan politik. Konsep ini tidak berbeda dengan regulasi yang menjadi dasar pelaksanaan Pilkada, yang dengan jelas tidak mendiskriminasi salah satu gender, tidak ada keistimewaan bahkan memberikan kesempatan yang sama pada laki-laki dan perempuan untuk berkesempatan berpartisipasi dalam politik, mereka berkesempatan berkompetisi secara terbuka untuk memperebutkan dan menempati jabatan-jabatan publik.

Keterwakilan perempuan dalam pesta demokrasi berdasarkan regulasi yang ada mengharuskan keterwakilan 30 persen perempuan pada kepengurusan partai politik ditingkat pusat untuk bisa menjadi peserta pemilu. Undang-undang no 10 tahun 2008 pasal 53 dengan tegas menyatakan bahwa calon peserta pemilu harus memuat paling sedikit 30 persen keterwakilan perempuan ${ }^{11}$. Regulasi tersebut menjadi dasar bagi perempuan untuk dapat mencalonkan diri sebagai calon peserta pemilihan kepala daerah. Sulawesi Tenggara merupakan salah satu daerah di Indonesia yang melaksanakan pilkada serentak baik tingakat Provinsi maupun tingakat Kabupaten Kota. Ada beberapa perempuan yang mencalonkan diri bertarung ditingkat lokal yang diharapkan bisa mendongkrak elektabilitas dan stigma yang selama ini disandang oleh perempuan di daerah ini.

Para srikandi yang berkompetisi pada Pilkada Sulawesi Tenggara berasal dari berbagai latar belakang profesi dan posisi sebelumnya, baik yang menjadi anggota legislatif di parlemen maupun yang berprofesi sebagai birokrat, dan menududuki posisi jabatan strategi di pemerintahan Kabupaten dan Kota. Para calon perempuan yang maju menjadi kandidat kontestan di Pilkada didukung oleh partai politik peserta pemilu dan dari unsur perseorangan. Lebih jelasnya dapat dilihat pada tabel dibawah ini:

\footnotetext{
${ }^{10}$ https://journal.unnes.ac.id/sju/index.php/snh 2018

${ }_{11}$ Undang-Undang No 10 Tahun 2016 Tentang Pemilihan Kepala Daerah
} 
Tabel 1: Calon Bupati/Walikota Pilkada Sulawesi Tenggara 2018

\begin{tabular}{|c|c|c|c|}
\hline & NAMA & КАВ/KOTA & PARTAI/PERSEORANGAN \\
\hline 1 & Hj. Asmani Arief & Kolaka & PKS dan Golkar \\
\hline 2 & Hj. Maasrah Manarfah & Bau-Bau & PBB dan Gerindra \\
\hline 3 & Hj. Roslina Rahim & Bau-Bau & PKB dan Hanura \\
\hline 4 & $\begin{array}{l}\text { Muliyati Saiman } \\
\text { jumlah }\end{array}$ & Konawe & $\begin{array}{l}\text { Perseorangan } \\
4 \text { orang }\end{array}$ \\
\hline
\end{tabular}

\section{Sumber Data Bawaslu Sulawesi Tenggara}

Partisipasi perempuan dalam pilkada tahun ini diakui oleh para pemerhati pemilu dan perempuan memang sangat minim bila dibandingkan dengan populasi perempuan yang mencapai 128 juta jiwa lebih, atau sekitar 49,2\% lebih dari jumlah penduduk Indonesia. Tingkat partisipasi perempuan dalam Pilkada sejak tahun 2015 memang tergolong rendah, apabila dibanding dengan afirmasi $30 \%$ bagi kuota perempuan.

Pemilihan Kepala Daerah yang dilakasanakan tanggal 27 Juni 2018 merupakan bentuk pemberian ruang demokrasi ditingkat lokal sekaligus menjadi ruang edukasi politik rakyat dalam menyalurkan aspirasi di daerah. Masyarakat dilatih untuk berdaulat dengan memilih pemimpin secara langsung, serta menjadi modal sosial terciptanya rasa kepedulian masyarakat pada negara dan bangsa dalam menentukan pemimpin.

Berdasarkan regulasi yang ada tentang pelaksanaan Pilkada serentak yang dilaksanakan secara serentak di seluruh negeri ini memberikan peluang dan kesempatan pada laki-laki dan perempuan untuk berkompetisi memperebutkan kursi nomor satu yang meligitimasi mereka menjadi pemimpin di daerah. Keterlibatan perempuan dalam kancah politik dalam kontestasi Pemilihan Kepala Daerah menjadi discourse yang ramai dan menarik. Gusti Kanjeng Ratu Hermas ketua Harian Presidium Kaukus Perempuan Parlemen RI mengatakan bahwa partisipasi perempuan menjadi hal penting untuk menjaga kualitas demokrasi Indonesia. Peningkatan keterwakilan perempuan akan meningkatkan perempuan yang bisa melakukan sesuatu bagi negeri ini ${ }^{12}$. Senada dengan hal tersebut, Direktur Eksekutif Perkumpulan untuk Pemilu dan Demokrasi (Perludem) Tity Anggraini menyatakan bahwa saat ini perempuan terjun di dunia politik terutama perempuan yang ikut kompetisi mendaftarkan diri menjadi Kepala Daerah kerap dianggap hal yang tabu, namun dalam Pilkada tahun 2018, keterlibatan perempuan mengalami kenaikan meskipun tidak signifikan, dari 101 perempuan atau 8,85\% jika dibandingkan pada dua Pilkada sebelumnya, dimana keterwakilan perempuan hanya 7, 47\% dalam Pilkada 2015, dan pada 2017, 7,17\%. Kehadiran perempuan harus dipandang secara lebih utuh dan tidak partisan, skeptisme dan pragmatisme. Demikian pula dengan ungkapan Siti Yona Hukmana, bahwa hal yang paling sulit adalah menghilangkan persepsi dan stigma masyarakat yang selalu memandang perempuan sebelah mata dalam kepemimpinan karena dinilai lemah, tidak tegas dan sulit dipercaya, tidak dapat maksimal melaksanakan tugas-tugas di ranah publik ${ }^{13}$.

Keraguan masyarakat nampaknya didasarkan pada fakta tradisi dan budaya politik bangsa, yang masih menganut budaya patriarkhis dan oligarkhis. Kesetaraan gender dalam ranah politik terlebih politik praktis yang terus digaungkan masih sebatas wacana dan issu

\footnotetext{
12 Gaffar, Janedjri M, Demokrasi Konstitusional, Praktek Ketatanegaraan Indonesia Setelah Prubahan UUD 1945, (Jakarta: Konstitusi Press (Konpress), 2013).

${ }^{13}$ Studi Perludem "Potret Perempuan Calon Kepala Daerah dalm Pilkada 2018
} 
dikarenakan selama ini masyarakat melihat perempuan yang terjun dalam politik belum mampu memberikan kontribusi yang optimal bagi upaya perbaikan politik dan advokasi kepentingan rakyat. Peneliti sosial Politik UGM Agung SS Widodo, mengungkapkan bahwa perempuan yang berada dalam wilayah politik praksis masih terlalu kecil dibandingkan lakilaki, pertanyaannya apakah perempuan memang tidak lebih layak (pantas) ataukah sistem kaderisasi partai politik yang masih saja bias gender dan cendrung patriarkhis. Perempuan hanya dianggap sebagai pelengkap dan penyedap semata ${ }^{14}$.

Koordinator Maju Perempuan Indonesia (MPI), Lena Maryana Muktimengatakan bahwaperempuan yang terjun dalam politik telah memenuhi syarat dan elektabilitas serta elektoral yang tinggi namun jumlahnya masih sedikit ${ }^{15}$. Perempuan peserta pilkada tahun 2018 naik meskipun tidak signifikan, mereka menghadapi kerikil akibat dari truss masyarakat bahwa keberadaan kepala daerah perempuan tidak 100\% gender responsive atau gender sensitive yang mengedepankan issu-issu perempuan. Undang-Undang Pilkada sebagai regulasi yang ada nampaknya tidak mengenal kebijakan khusus dalam mengusung calon perempuan seperti kebijakan afirmasi perempuan pada pemilihan legislatif, ditambah lagi gelaran pilkada hanya satu putaran membuat kompetisi semakin ketat dan mempersulit ruang dan peluang perempuan untuk menang yang memang kuantitasnya sedikit. Menurut Direktur Eksekutif Perludem untuk bisa meminimalisir kondisi tersebut maka upaya yang harus dilakukan adalah paling tidak menempuh dua jalur, yakni melalui partai maupun perseorangan/independen. Realitasnya memang demikian bahwa semua perempuan yang lolos menjadi calon dalam Pilkada adalah usungan partai politik dan melalui perseorangan/independen, baik ditingkat Provinsi maupun Kabupaten/Kota.

\section{Dinamika Eksisitensi Peserta Pilkada}

Pemilihan Kepala Daerah (Pilkada) Sudah Dilaksanakan Secara Serentak Diseluruh Indonesia, termasuk Sulawesi Tenggara di tiga Kabupaten/Kota. Pelaksanakan pilkada merupakan barometer dalam demokrasi, bagaimana masyarakat berpartisipasi dan memanfaatkan kesempatan berperan aktif dalam pesta demokrasi yang hanya dilaksanakan satu kali dalam jangka waktu lima tahun. Sulawesi Tenggara merupakan salah satu daerah yang melaksanakan pemilihan kepala daerah ditingkat Provinsi (pemilihan Gubernur) dan Kabupten/Kota (Bupati dan Walikota). Sebagaimana data awal bahwa ada 10 pasangan calon Bupati/Walikota yang akan berkompetisi, dari semua pasangan calon kepala daerah di Kabupaten Kota yang akan melaksanakan pilkada, ada 4 pasangan calon adalah perempuan yang berasal dari gabungan partai politik dan dari unsur perseorangan/independen.

Secara keseluruhan calon Bupati dan Walikota dalam Pilkada di Sulawesi tenggara sejak pendaftaran hingga penetapan menjadi calon peserta Pilkada oleh KPU Provinsi Sulawesi Tenggara berjumlah 4 orang yaitu; Kota Bau-Bau diikuti 2 pasangan calon, Kabupaten Kolaka 1 pasangan calon dan Kabupaten Konawe diikuti 1 pasangan calon. dari unsur independen atau perseorangan dengan dukungan KTP kurang lebih 24.000. Perlu dijelaskan bahwa latar belakang kandidat atau calon perempuan tersebut berasal dari legslatif, eksekutif dan birokrasi, yakni; (a) Hj. Roslina Rahim adalah ketua DPRD Kota Bau-Bau priode 2013-2019, (b) Hj. Wa Ode Maasra Manarfa adalah wakil Walikota Bau-Bau priode 2012-2018, (c) Hj. Asmani Arief adalah Seketaris Daerah Kabupaten Kolaka, dan Muliati Saiman, S.Si adalah anggota DPD RI priode 2013-2019'

\footnotetext{
${ }^{14}$ Suswantoro Gunawan, 2016. Mengawal Penegak Demokrasi di Balik Tata Kelola Bawaslu \& DKPP, Jakarta: Erlangga, 2016.

15 Budiarti Aisah Putri, Politik dan Perempuan, Departemen Ilmu Politik Fak Ilmu Sosial dan Ilmu Politik Univ Indonesia, 2011,

${ }^{16}$ Data dari Panwas Kabupaten Konawe, Kolaka, dan Kota Bau-Bau
} 
Hasil wawancara dengan penyelenggara di tiga Kabupaten dan Kota yang melaksanakan Pilkada, terungkap bahwa secara umum selama proses Pilkada berlangsung semua calon peserta pilkada perempuan telah melakukan berbagai upaya dan strategi untuk memenangkan kompetisi dan meraih simpati serta dukungan masyarakat pemilih. Stategi yang dilaksanakan sesuai dengan mekanisme dan regulasi yang ada, yaitu melakukan;

(1) Sosialisasi, semua calon melakukan sosialisasi sebelum ditetapkan sebagai calon, yakni dengan memasang baliho, spanduk, bilbord, melalui media cetak dan elektronik, mengunjungi tokoh agama, tokoh adat, organisasi masyarakat, pemuda, organisasi keagamaan, bahkan memperkenalkan diri dalam kegiatan atau acara yang dihadiri banyak massa, juga melakukan kegiatan dengan mengumpukan massa dengan membuat kegiatan seperti mengundang Majelis Taklim untuk melaksanakan pengajian dengan menghadirkan Dai/Ustaz/Ustazah sebagai penceramah. Demikian pula ada calon yang memberikan/membagikan barang kepada masyarakat pada saat sosialisasi atau pertemua terbatas, seperti mukenah, al-quran, sembako, payung, kacamata, sarung, baju, topi/kopiah, dan memberikan bantuan alat-alat olah raga dan lain-lain, yang nilainya tidak lebih dari Rp 25.000 (dua puluh lima ribu rupiah).

(2) Memaksimalkan keluarga, kolega dan kerabat, selain tim kampanye dan mesin partai, peran keluarga, kolega dan kerabat sangat besar, mengingat semua calon masih memiliki ikatan kekelurgaan, kekerabatan serta mitra/kolega kerja. Yang paling dibutuhkan setiap calon adalah kemampuan mempengaruhi dan meyakinkan bagai mana menarik simpatik mereka.

(3) Blusukan, yang dilakukan dengan mendatangi rumah warga dengan membentuk tim pemenangan disetiap Kecamatan, Desa dan Kelurahan, bahkan kampung/plosok. Mereka mengumpulkan warga dirumah tim pemenangan yang telah ditetapkan melalui surat keputusan dari calon. Dalam penyampaiannya/orasinya pada masyarakat tetap menegdepankan perjuangan untuk kepentingan gender perempuan, karena sebagai calon perempuan yang tetap memihak pada kepentingan perempuan. Calon juga berkunjung kepasar, ketempat masyarakat yang tinggal di daerah kumuh dan terpencil.

(4) Dialog Terbuka, dilakukan dengan berdialog secara terbatas pada masyarakat dibeberapa tempat baik itu di ibu kota Kabupaten/Kota, Kecamatan atau Desa/Kelurahan, mereka meyakinkan pada masyarakat dengan janji apabila menjadi pemimpin maka akan memenuhi kebutuhan ekonomi dan mensejahtrakan rakyat (pedagang kaki lima, tukang ojek, dll), memberikan pupuk dan bibit pertanian, membangun fasiltas dan sarana umum sebagai kebutuhan masyarakat, terutama akses jalan-jalan dilorong dan perkampungan serta mengaspal jalan yang rusak, pendidikan, kesehatan serta pengangguran.

(5) Kampanye Terbuka, dilakukan oleh semua calon sesuai dengan jadwal dari KPU, yang dilakukan di lapangan terbuka dengan mengumpulkan sebanyak mungkin massa. Semua calon memberikan orasi dengan memaparkan visi, misi, dan program kerja apabila menjadi pemimpin.

Semua calon dalam melakukan soaialisasi dan kampanye tidak luput dari pelanggaran pemilu. Hal ini sesuai hasil observasi dan wawacara dengan Panwas Kolaka, Konawe dan Bau-Bau, bahwa selama pelaksanaan kampanye para kandidat calon Pilkada telah melakukan berbagai macam pelanggaran, baik pelanggaran yang dilaporkan oleh masyarakat maupun pelanggaran hasil temuan pengawas pemilu. Pelanggaran tersebut dilakukan oleh calon peserta maupun dari tim sukses dan relawan, sebahagian besar dikarenakan tim kampanye dan relawan tidak memahmi dengan benar aturan/regulasi pemilu dan juga dikarenakan 
ketidak mampuan menajemen dan ketidak jelasan pembagian job atau tugas masing, baik LO maupun tim kampanye.

Beberapa pelanggaran pemilu yang dilikaukan para calon Pilkada antara lain;

(a) Dr. Hj. Asmanin Arief calon kabupaten Kolaka, melakukan pelanggaran yakni kampanye di luar jadwal, membuat dan memasang baliho atau alat praga yang tidak sesuai dengan aturan desain dan master dari KPU, memberikan barang/sembako pada saat kampanye atau pertemuan terbatas yang nilainya melebihi ketentuan, pelibatan PNS. Beberapa pelanggar telah diproses Panwas Kolaka dan di bahas ditingkat Gakumdu.

(b) Muliati Saiman, S.Si, melakukan pekanggaran yakni, melakukan pelanggaran yakni kampanye di luar jadwal, membuat dan memasang baliho atau alat praga yang tidak sesuai dengan aturan desain dan master dari KPU dan diletkkan di area atau zona yang tidak ditentukan oleh KPU, sengketa acara cepat terkait pemasangan penggunaan Alat Praga Kampanye. Untuk pelanggaran Acara Sengketa Cepat diproses oleh Panwas Kabupaten Konawe yakni calon bersengketa atau berselisih dengan calon dari usungan PDIP atas nama Hj. Murni Litanto. Demikian pula dengan pelanggaran pemasangan alat Praga Kampanye dan kampanye di luar jadwal diproses oleh Panwas Konawe dan naik ke tingkat pengadilan, hasilnya calon dinyatakan bersalah dengan pidana dengan denda 1 juta rupiah.

(c) Hj. Roslina Rahim, pelanggaran yang dilakukan yakni (1) melakukan pelanggaran yakni kampanye di luar jadwal. Pelanggaran ini diregistrasi oleh Panwas Kota Bau-Bau dan diproses dan dibahas pada pembahasan II di tingkat Gakumdu. (2) Pelibatan PNS yaitu suaminya sendiria an. Abd. Rahim, ksusnya ditangani oleh diregistrasi dan di proses oleh Panwas Kota Bau-Bau, dan putusannya adalah dinyatakan terbukti, dan Panwas Kota Bau-Bau kemudian merekomendasikan pada Komisi Aparatur Sipil Negara (KASN). Hasil dari rekomendasi Panwas Bau-Bau adalah yang bersangkutan divonis dengan hukuman disiplin sedang.

(d) $\mathrm{Hj}$. Wa Ode Maasara Manarfah selama kampanye Pilkada telah dilaporkan pada Panwas Bau-Bau beberapa pelanggaran naum setelah diproses hanya 1 yang dinyatakan tebukti dan memenuhi syarakat. Kasusnya adalah kampanye di luar jadwal dan telah nyatakan terbukti oleh Pengadilan Negeri Bau-Bau. Hukumannya adalah 1 bulan dan percobaan 2 bulan. Pelanggaran

\section{Peluang Dan Tantangan Perempuan dalam Pilkada}

Pemilihan Kepala Daerah secara serentak di seluruh Indonesia sudah dilaksanakan pada tanggal 27 Juni 2018 yang lalu termasuk Sulawesi Tenggara. Pelaksanaannya berjalan dengan aman, damai dan kondusif, meskipun beberapa daerah melaksanakan PSU (Pemungutan Suara Ulang) yang disebabkan adanya beberapa pelanggara yang terjadi, baik yang dilakukan oleh Penyelenggara, masyarakat (pemilih) maupun bersifat teknis. Pelaksanaan PSU di Sulawesi Tenggara dilakasanakan pada 41 TPS termasuk tiga Kabupaten/Kota yang pilkada yaitu Kabupaten Konawe 1 TPS dan Bau-Bau 4 TPS.

Pada saat tulisan ini disusun, hasil perolehan suara setiap pasangan calon baik ditingkat Provinsi maupun Kabupaten Kota sudah selesai dilakukan proses penghitungan suara mulai di tingkat PPK (Panitia Pemilihan Kecamatan) sampai KPU Privinsi, hasil perolehan suara masing-masing calon baik calon Gubernur maupun Bupati/Walikota sudah ditetapkan meskipun penetapan finalnya masih menunggu putusan Mahkamah Konsititusi.

Berikut dijelaskan peroleh suara masing-masing pasangan calon Bupati dan Walikota yang mengikuti Pemilihan Kepala Daerah di tiga Kabupaten/Kota sebagaimana tabel berikut: 
Tabel 2: Perolehan Suara Masing-Masing Calon Pilkada

\begin{tabular}{llll}
\hline NO & NAMA & KAB/KOTA & PEROLEHAN SUARA \\
\hline $\mathbf{1}$ & $\begin{array}{l}\text { H. Ahmad Safei, SH, MH \& } \\
\text { H. Muhammad Jayadi, SE, ME }\end{array}$ & 37,153 \\
& $\begin{array}{l}\text { Hj. Asmani Arief \& } \\
\text { Syahrul Beddu, SIP }\end{array}$ & 21,930 \\
\hline $\mathbf{2}$ & $\begin{array}{l}\text { Kery Saiful Konggoasa \& } \\
\text { Gusli Topan Sabara, ST. MM }\end{array}$ & \\
& $\begin{array}{l}\text { H.Utanto, Sh, M.Si \& Hj. } \\
\text { Murni Tombili }\end{array}$ & 27,04 \\
& $\begin{array}{l}\text { Irawan Laliasa, SE, M.Si \& } \\
\text { Adi Jaya Putra, B.Bus, M.Kom } \\
\text { Muliati Saiman, S.Si \& Ir. } \\
\text { Masur, MP }\end{array}$ & 18,78 \\
\hline Dr. H. AS. Tamrin, MH \& & 2,13 \\
Laode Ahmad Monianse & BAU-BAU & 23.573 \\
Hj. Roslina Rahim \& La Ode & & 18.367 \\
Yasin & $\begin{array}{l}\text { Drs. H. Ibrahim Masrela, MM } \\
\text { \& Ilyas, S.Sos } \\
\text { Hj. Wa Ode Maasra } \\
\text { Manarfa \& Ikhsan Ismail }\end{array}$ & 9.371 \\
\hline
\end{tabular}

Sumber data:KPUD dan Panwas Kabupaten Kolaka, Konawe dan Kota Bau-Bau

Mencermati hasil perolehan suara masing-masing calon diatas, sudah bisa di prediksi bahwa tidak ada calon perempuan yang memperoleh suara tertinggi. Kondisi ini sangat miris dan memprihatinkan mengingat pemilih perempuan di Sultra kuantitasnya sangat tinggi. Menjadi pertanyaan apakah calon perempuan tidak bisa menyentuh pemilih perempuan dengan tawaran program, kharismatik jalinan kerjasama perempuan, dan nilai jual calon perempuan tidak bisa melampaui calon laki-laki ataukah strategi dan kesiapan calon laki-laki lebih matang dan sistimatis dalam menghadapi dan melakukan semua tahapan pemilihan, terutama kemampuan semua timsukses dan relawan dalam meyakinkan pemilih.

Kegagalan para kandidat dalam kompetisi Pilkada dari hasil pengamatan disebabkan oleh beberapa faktor antara lain; (1) kompetitor adalah incumbent yang sudah memiliki jaringan dari jajaran birokrat yang sistimatis, basis yang jelas, finansial/budget yang besar, program kerja yang sudah dirasakan masyarakat serta tim pemenangan yang solid, (2) isu prespektif gender dalam visi, isi dan program mereka masih bersifat umum tanpa penyebaran lebih lanjut dalam turunan yang substantif. Visi, misi dan program kerja dari semua pasangan calon perempuan nampaknya terlalu mengambang, universal, general, teoritis, hampir tidak adayang spesifik langsung bersentuhan dengan keberadaan dan kebutuhan perempuan pada semua strata (kalangan), di Desa, di Kota mapun perempuan yang tinggal daerah terpencil. Meskipun para calon perempuan adalah orang-orang yang sudah lama berkecimpung dalam dunia eksekutif dan birokrasi, seyogyanya sudah memahi betul kebutuhan masyarakat terutama pemilih perempuan. Kondisi ini sesuai dengan observasi dan wawancara dengan Panwas Kolaka, Konawe dan Bau-Bau yang intinya bahwa ketidak berhasil perempuan lolos menjadi Bupati dan Walikota disebabkan oleh beberapa hal antara lain; (1) program yang ditawarkan belum sepenuhnya berafiliasi pada perempuan, (2) kepercayaan (truss) masyarakat terhadap kompetensi, kualitas dan kapabilitas perempuan masih rendah, hal ini 
menurut para pengamat politik dan aktivis perempuan, bahwa afirmasi keterwakilan perempuan yang menjabat kepala daerah tercederai dengan banyak kepala daerah yang tersandung kasus korupsi, (3) kemampuan dan soliditas serta koordinasi timsukses dan relawan yang lemah, (4) kandidat yang menjadi lawan kompetitor adalah petahana/incumben yang sudah sejak awal membuat program dan starategi kemenangan yang didasarkan pada pengalaman sebelumnya.

Menurut Maharddika, dari 37 paslon perempuan tidak mampu meyakinkan pemilih mereka tidak semua memiliki visi, misi dan program yang presfektig gender, tidak menggambarkan kebutuhan perempuan secara spesifik tidak dapat meyakinkan pemilih ${ }^{17}$. Titi Anggraini, kegagalan perempuan dalam Pikada tidak terlepas dari ketiadaan kaderisasi yang dilakukan oleh Parpol dalam mempersiapkan perempuan, mereka mengusung perempuan berdasarkan elektabilitas, popularitas, politok dinasti, kekerabatan, atau bagaian dari jaringan parpol. Dijelaskan pula bahwa perempuan dan pilkada merupakan keniscayaan untuk mengisi kursi pimpinan pemerintahan, kenyataannya masih didominasi oleh maskulin dan karakteristik patriarki, belum sepenuhnya respon gender dan memperhatikan affirmative action.

Eksistensi perempuan dalam kancah pemilihan kepala daerah di Sulawesi Tenggaramenjadi perhatian tersendiri, dimana sejak pelaksanaan pilkada serentak tahun 2015 dan 2017 tidak ada calon perempuan, jadi baru kali ini semua daerah mempunyai pasangan calon kepala daerah perempuan. Hal ini menjadi menarik dan penting serta peringatan bagi kontestan laki-laki untuk tidak lengah dan lebih waspada, mengingat kontestan perempuan yang ada adalah perempuan yang memiliki kompetensi, daya dukung dari partai pengusung, keluarga yang berpengaruh, kekerabatan, pengalaman menjadi anggota parlemen, dan meiliki massa dan basis yang jelas.

Ditemukan hasil bahwa partisipasi perempuan dalam pemilihan kepala daerah di Sulawesi Tenggara cukup signifikan, ada kenaikan partisipasi apabila dibanding dengan daerah lain. Hal ini dapat dilihat dari jumlah perempuan yang lolos sebagai calon walikota dan Bupati di 3 daerah Kabupaten/Kota Sulawesi Tenggara. Kondisi ini tentu tidak terlepas dari kesadara semua pihak terutama partai politik yang memberikan kesempatan pada perempuan mengambil peran politik dalam kompetisi pesta demokrasi yang digelar secara serentak di seluruh nusantara. Mayoritas calon kepala daerah yang bertarung memperebutkan kursi nomor satu di daerahnya adalah berasal dari kader partai dan mantan anggota parlemen, memiliki jaringan kekerabatan dengan pemimpin partai dan petahana. Para kandididat akan memaksimalkan pengalaman dan dukungan partai, jaringan kolega, kekerabatan untuk mendulang suara memenangkan kompetisi.

Perhelatan pilkada di Kota Bau-Bau ada yang menarik untuk disimak adalah berdasarkan dokumen dan wawnacara Panwas Bau-bau divisi penanganan pelanggaran, yang menjelaskan bahwa salah satu pasangan calon urut nomor satu ditetapkan menjadi salah satu pasangan calon setelah melalui sengketa di di Panwas Kota Bau-Bau, yang hasilnya merekomendasikan bahwa KPU harus membatalkan pencalonan nomor urut satu dikarenakan kasus pemalsuan SKCK (Surat Keterangan Catatan Kepolisian) dari kepolisian. KPU bisa menetapkan kembali setelah pasangan calon dapat menyelesaikan dan membuktikan kebenaran dan mendapatkan rekomendasi dari kepolisian Bau-Bau bahwa SKCK benar adanya, dan yang bersangkutan tidak melanggar etika moral pelecehan. Setelah batas waktu yang diberikan oleh KPU, dan semua pensyaratan dipenuhi oleh pasangan calon maka KPU

${ }^{17}$ Richaldo Y. Hariandja, "Kandidat Perempuan Minim Program Pro Perempuan di Pilkada 2018". Harian Media Indonesia, Senin, 02 Sep 2019. 
kembali menetapkan pasangan calon atas nama $\mathrm{Hj}$. Roslina Rahim \& La Ode Yasin untuk menjadi pasangan calon dalam Pilwali Bau-Bau yang kemudian menjadi nomor urut 1 (satu).

Kasus tersebut nampaknya mempengaruhi elektabilitas dan popularistas, memberikan citra negatif calon yang bersangkutan. Kondisi tersebut nampaknya tidak disia-siakan oleh kompetitor lain meyakinkan masyarakat pemilih untuk memilih calon yang bersih, baik dan berintegritas, akibatnya sangat beririsandan berdampak pada hasil perolehan suara. Kondisi lain juga dialami oleh calon perempuan di Kolaka dan Konawe, Informasi dari Calon dan tim sukse menjelaskan bahwa calon perempuan di kabupeten mereka menglami kondisi yang sulit "kami mengalami kesulitan dilapangan dikarenakan kandidat yang menjadi lawan salah satunya adalah calon incumben, yang nota bene sudah mempunyai modal dan saham baik material maupun non material. Para pejabat dan aparat yang diangkat oleh incumben mereka pasti akan membalas budi dengan berupaya membantu dalam dukungan pada incumben dengan berbagai cara termasuk pelibatan PNS dan non PNS"19. Mereka harus menghadapi serangan lawan melalui media cetak dan media sosial, apakah itu masalah pribadi ataupun tidak adanya kontribusi yang diberikan selama menjadi pejabat dilingkungan masing-masing, dipandang skeptis tidak memberikan nilai tambah yang positif, terutama kepada perempuan. Calon perempuan tidak dapat mendongrak popularistas dan elektabilitas mereka dengan menawarkan suatu program atau kegiatan yang jelas, realistis, ramah, terukur yang bersentuhan langsung serta dampaknya dapat dirasakan masyarakat khususnya perempuan disemua kalangan, status atau strata serta tidak bias gender.

Tidak dapat dipungkiri bahwa perempuan yang terjun dalam politik akan menghadapai berbagai rintangan. Ketika perempuan mengalami masalah baik hukum maun moral, maka eksistensi keperempuanannya akan ikut digugat. Espektasi publik terhadap perempuan terkadang terjadi diskriminasi bila di bandingkan dengan laki-laki. Tagihan pada perempuan politik nampaknya ganda, dimana pada saat yang bersamaan mereka harus menjadi politis etis perempuan yang berintegritas. Kondisi ini memberikan sinyal bahwa sistim politik yang dikonstruksi oleh masyarakat cendrung belum kondusif dan belum ramah perempuan. Langkah-langkah yang harus dilakukan perempuan untuk meningkatkan keterwakilan perempuan dalam politik dan pembangunan, menurut Titi Anggraini diantaranya: pelunya penerapan kebijakan affirmative action dalam desain aturan main penyelenggaraan pilkada serentak dengan cara mempermudah syarat pencalonan bagi calon kepala daerah atau wakil kepala daera perempuan, seperti; 1) pengurangan syarat minimal dukungan bagi perempuan yang maju melalui jalur perseorangan, 2) pengurangan ambang batas minimal kursi DPRD bagi partai politik yang mencalonkan perempuan. partai politik dapat menerapkan mekanisme kuota pencalonan perempuan di internal partai politik untuk meningkatkan jumlah calon perempuan di pilkada. Adanya insentif dari negara berupa biaya kampanye bagi perempuan di pilkada.

\section{E. Penutup}

Berdasarkan permasalahan dan temuan penelitian perempuan peserta calon pemilihan kepala daerah di Sulawesi Tenggara, maka disimpulkan bahwa Kehadiran perempuan sebagai kompetitor dalam pesta demokrsi pemilihan kepala daerah pada tahun ini yang disebut sebagai tahun politik menjadi jawaban bahwa perempuan sudah eksis dan diperhitungkan keberadaannya dalam semua bidang, bukan hanya domestik, namun mampu memposisikan diri dalam berkompetisi pada ranah publik. Tidak dapat dipungkiri bahwa eksistensi perempuan dewasa ini sebagai pembuktian bahwa perempuan tidak lagi hanya menjadi objek dan pelengkap yang hanya mampu melakukan tugas-tugas domestik,

\footnotetext{
${ }^{19}$ Wawancara dengan Tim Kampanye Kabupaten Kolaka tgl 9 Juni 2018.
} 
mengurus keluarga, organisasi, atau lembaga yang sifatnya terbatas. Potret kongkrit calon perempuan dalam Pilkada, masih didominasi oleh dukungan/usungan partai. Ada dua hal yang mendasari mengapa partai mengusung perempuan, yakni faktor elektabilitas (politik dinasti, kekerabatan) dan faktor kekutan modal, bukan berdasarkan kualitas dan kompetensi dari hasil mekanisme perekrutan yang inklusif dan terbuka. Akibatnya mereka tidak maksimal maraih simapti dan meyakinkan masyarakat pemilih akan eksistensi sebagai kandidat yang kompeten.

Semua calon peserta Pilkada tidak terkecuali calon perempuan telah melakukan berbagai strategi sebagi upaya memenangkan kompetisi. Namun tidak mudah bagi calon perempuan disebabkan lawan kompetitor adalah incumben/petahan, ditambah lagi visi, misi dan program yang ditawarkan tidak menunjukkan keberpihakanpada agenda isu-isu responsif gender perempuan, seperti; perlindungan anak, angka kematian ibu melahirkan, angka pengangguran perempuan/lapangan kerja perempuan, anak terlantar/jalanan, korban TKW, korban kekerasan KDRT, kesejahtraan petani dan buruh perempuan, perdagangan anak, dan lain sebaginya. Selain itu calon perempuan belum kuat melawan stigma negatif yang sering dilabelkan masyarakat termasuk dari perempuan, kepercayaan tentang rendahnya kompetensi dan kualitas calon perempuan dalam konteks nasional, lokal bahkan sektoral. Stigma tersebut diperparah dengan banyak kepala daerah perempuan yang tersandung kasus korupsi dan penyahgunaan wewenang. Afirmasi keterwakilan perempuan dalam kancah politik di Pilkada secara kuantitas memang meningkat namun tidak signifikan dengan keberhasilan dan kesusukesan meraih suara posisi tertinggi.

Regulasi yang menjadi dasar pelaksanaan Pilkada tidak mengenal kebijakan khusus bagi calon perempuan. Kondisi ini diperparah dengan pelaksanaan Pilkada yang hanya digelar satu putaran. Bagi calon perempuan di Sulawesi Tenggara hal ini akan menyulitkan mengingat persaingan amat ketat, dikarenakan kompetitor adalah incumben/petahana yang sudah terlebih dahulu membuat kebijakan dengan program yang strategis dan sudah menegosiasikan dengan lembaga legislatif (DPRD). Mereka sudah memiliki modal awal dan nilai jual untuk meyakinkan masyarakat pemilih demikian pula regulasi yang ada tidak memberikan peluang dan ruang dengan mudah bagi calon perempuan.

\section{DAFTAR PUSTAKA}

Iskandar, Israr "Wali Nagari Perempuan Di Era Reformasi: Studi Kasus Terpilihnya Wali Nagari Batu Basa Kecamatan Pariangan Kabupaten Tanah Datar Tahun 2009”, Aspirasi Vol. 2 No. 1, (Juni 2011): 97-110

Gaffar, Janedjri M, Demokrasi Konstitusional, Praktek Ketatanegaraan Indonesia Setelah Perubahan UUD 1945, (Jakarta: Konstitusi Press (Konpress), 2013).

Gunawan, Suswantoro Mengawal Penegak Demokrasi di Balik Tata Kelola Bawaslu \& DKPP, (Jakarta: Erlangga, 2016).

Hariandja, Richaldo Y. "Kandidat Perempuan Minim Program Pro Perempuan di Pilkada 2018”. Harian Media Indonesia, Senin, 02 Sep 2019.

https://journal.unnes.ac.id/sju/index.php/snh 2018

Kementerian Pemberdayaan Perempuan dan Anak. https:kemenpppa.go.id

KPU dan Bawaslu Sulawesi Tenggara 2017 
Marwah, Sofa "Representasi Perempuan Dalam Pemilihan Bupati Dan Wakil Bupati Serentak Di Jawa Tengah Tahun 2015", JURNAL POLITIK, VOL.1, NO. 2, (Februari 2016): 264-281.

Putri, Budiarti Aisah Politik dan Perempuan, Departemen Ilmu Politik Fak Ilmu Sosial dan Ilmu Politik Univ Indonesia, 2011

Studi Perludem "Potret Perempuan Calon Kepala Daerah dalm Pilkada 2018

Teguh, Prasetyo Pemilu Bermartabat (Reorientasi Pemikiran Baru Tentang Demokrasi, Jakarta: Raja Grafindo Persada, 2017.

Undang-Undang Nomor 10 Tahun 2016 Perubahan Kedua Undang-Undang Nomor 1 Tahun 2015 Tentang Penerapan Peraturan Pemerintah Pengganti Undang-Undang Nomor 1 Tahun 2014 Tentang Pemilihan Gubernur, Bupati Dan Walikota.

Undang-Undang No 10 Tahun 2016 Tentang Pemilihan Kepala Daerah

Wahid, Umaimah "Perempuan Dan Kekuasaan Politik Dalam Pemilukada Dki Jakarta Tahun 2012”, Jurnal Komunikasi Malaysian Journal of Communication Jilid 29(1) 2013: 73-97

Zainal, Asliah "Politik Berjenis Kelamin Laki-laki (Keterwakilan Perempuan Di DPRD Provinsi Sulawesi Tenggara Pada Pemilu 2014)”, Jurnal Al Izzah Vol. 10 No. 1 2015, http://ejournal.iainkendari.ac.id/index.php/al-izzah/article/view/325. DOI: http://dx.doi.org/10.31332/ai.v10i1.325 